\title{
Pengelolaan Investasi terhadap Laporan Keuangan Pada Yayasan Tunjangan Hari Tua Bank Sumsel Babel
}

\author{
Aries Veronica ${ }^{1}$, Selvi Erianda ${ }^{2}$ \\ ${ }^{1}$ Fakultas Ekonomi, Universitas Tamansiswa, aries veronica@unitaspalembang.ac.id \\ ${ }^{2}$ Fakultas Ekonomi, Universitas Tamansiswa, eriandaselvi@gmail.com
}

\begin{abstract}
ABSTRAK
Tujuan dari penelitian ini adalah untuk mengetahui manajemen investasi laporan keuangan di Yayasan Tunjangan Hari Tua Bank Sumsel Babel. Teknik pengumpulan data dilakukan melalui metode dokumentasi dengan mengambil data laporan keuangan bulanan dari Yayasan Tunjangan Hari Tua Bank Sumsel Babel. Analisis yang digunakan dalam penelitian ini adalah analisis regresi linier berganda. Variabel dependen dari penelitian ini adalah Laporan Keuangan $(Y)$ dan untuk variabel independen termasuk Setoran (X1), Obligasi (X2), dan Saham (X3). Hasil penelitian ini menunjukkan Setoran (X1), Obligasi (X2), dan Saham (X3) memiliki hubungan dan memiliki pengaruh signifikan terhadap Laporan Keuangan (Y) sebesar $71,7 \%$. Berdasarkan pembahasan dapat disimpulkan bahwa manajemen investasi pada deposito, obligasi, dan saham memiliki pengaruh positif signifikan terhadap laporan keuangan Yayasan Tunjangan Hari Tua Bank Sumsel Babel.
\end{abstract}

Kata kunci: Investasi, Deposito, Obligasi, Saham, Laporan Keuangan

\section{A. PENDAHULUAN}

Pengelolaan dinyatakan juga dengan serangkaian kegiatan untuk mencapai sasaran-sasaran tertentu dengan menggunakan orang-orang sebagai pelaksananya (Purwanto, 2009). Investasi merupakan salah satu faktor yang penting dalam pengelolaan dana pada sebuah peusahaan. Investasi dapat dilakukan pada aktiva real ataupun finansial asset atau sekuritas (commercial paper, saham, obligasi, atau sertifikat reksadana). (Husnan, 2015).

Investasi merupakan salah satu cara perusahaan dalam mengoptimalkan penggunaan kas jika terjadi surplus. Investasi dapat dimaksudkan sebagai akumulasi dari suatu bentuk aktiva untuk memperoleh manfaat dimasa yang akan datang. Pemanfaatan surplus kas untuk memperoleh pendapatan dalam jangka panjang dan memanfaatkan dana yang belum digunakan untuk investasi jangka pendek dalam rangka manajemen kas. Perlakuan akuntansi untuk investasi dalam laporan keuangan beserta pengungkapannya diatur dalam PSAK 13. ( IAI, 2018).

Yayasan Tunjangan Hari Tua Bank Sumsel Babel merupakan lembaga keuangan dengan program jangka panjang yang mengelola dana pensiunan untuk memberikan manfaat pensiunan yang diberikan secara berkala sekaligus saat Peserta memasuki masa pensiun, bisa diterimakan kepada janda/duda, anak atau ahli waris Peserta yang sah apabila Peserta meninggal dunia.Sumber dana yang dihimpun oleh Yayasan Tunjangan Hari Tua Bank Sumsel Babel berasal dari luran Pendiri (Bank Sumsel Babel) dan luran Peserta (karyawan Bank Sumsel Babel).

Investasi memiliki peran yang penting untuk pengelolaan dana pensiunan di Yayasan Tunjangan Hari Tua Bank Sumsel Babel, dengan 
mengelola dana keuangan perusahaan diharapkan dapat membayar biayabiaya operasional dan kewajibannya. Manajemen keuangan dan investasi berusaha menentukan ukuran-ukuran yang dapat digunakan untuk melihat layak tidaknya suatu bentuk Investasi atau seberapa besar keberhasilan suatu investasi dalam memenuhi kewajiban yang diharapkan.

Pada Yayasan Tunjangan Hari

Tua Bank Sumsel Babel tujuan berinvestasi adalah untuk mendapatkan tingkat pengembangan yang tinggi dengan tingkat resiko yang kecil untuk memenuhi kewajiban pembayaran manfaat pensiunan kepada para Peserta Pensiunan maupun untuk pertumbuhan kinerja perusahaan.

Dalam investasi di Yayasan Tunjangan Hari Tua Bank Sumsel Babel, sebagai investor memiliki tanggung jawab systematic risk dan unsystematic risk ini dilakukan agar suatu bisnis sukses dan dapat menguntungkan bisnis harus dijalankan berdasarkan atas keputusan yang sehat, bijaksana dan hati-hati. (sarjanaku.com/2012)

Meraih keuntungan dari pengelolaan dana dapat dilihat dari kebijakan investasi yang diterapkannya. Kebijakan investasi itu dapat dilihat dari pemilihan bentuk investasi. Maka, dibutuhkan orang yang berkompeten untuk melakukan kegiatan investasi yang bertujuan memberiikan perkembangan yang baik untuk suatu perusahaan. Sebab investasi yang dilakukan akan menentukan tingkat keuangan dan kemajuan program Tunjangan Hari Tua. Dalam mengelola dan mengembangkan dananya, pengurus Yayasan Tunjangan Hari Tua Bank Sumsel Babel pada saat ini melakukan kegiatan investasi dalam bentuk deposito, obligasi, dan saham.
Menurut Standar Akuntansi, laporan keuangan merupakan bagian dari proses pelaporan keuangan. Laporan keuangan yang lengkap biasanya meliputi neraca, laporan labarugi, laporan perubahan posisi keuangan (yang dapat disajikan dalamberbagai cara misalnya, sebagai laporan arus kas, atau laporan arus dana),catatan dan laporan lain serta materi penjelasan yang merupakan bagianintegral dari laporan keuangan. Disamping itu juga termasuk skedul daninformasi tambahan yang berkaitan dengan laporan tersebut, misalnya, informasi keuangan segmen industri dan geografis serta pengungkapan pengaruh perubahan harga. (PSAK No.1, 2018)

Perkembangan keungangan dari Yayasan Tunjangan Hari Tua Bank Sumsel Babel ini dapat dilihat dari laporan keuangannya. Laporan yang menunjukkan kondisi keuangan perusahaan pada saat ini atau dalam suatu periode tertentu (Kasmir,2014). Yayasan Tunjangan Hari Tua Bank Sumsel babel melakukan Pengelolaan Investasi dengan mengelola dana bagi hasil yang didapat dari kegiatan investasi. Pengelolaan ini diharapkan dapat berdampak positif bagi kinerja perusahaan dimana keuntungan pengelolaan dana dapat menghasilkan pemberian manfaat tunjangan hari tua yang maksimal dan mencukupi bagi seluruh peserta tunjang hari tua, melihat banyaknya peserta tunjangan hari tua pada Bank Sumsel Babel.

Penelitian yang dilakukan oleh Sayuti, dkk (2015), yang berjudul Pengelolaan Investasi Dana Pensiun Pada DAPENSRI PT.Pupuk Sriwidjaja Palembang. Dapensri melakukan berbagai investasi agar dana yang terkumpul dapat menghasilkan return yang maksimal dan tetap sesuai dengan arahan investasi yang diberikanpendiri, hasil pengelolaan 
dananya dapat dilihat dari laporan keuangan. Sedangkan Aniqoh (2008) melakukan penelitian dengan tujuan untuk mengetahui fungsi bagian investasinya pada divisi keuangan di BUMIDA, pengelolaan dana asuransi ini dilakukan untuk menjaga kesehatan keuangan perusahaan agar tetap solvent yang artinya mampu membayar biaya operasi dan kewajibannya

Pada PT. Taspen Rulyanto (2008), juga menemukan hasil bahwa perusahaan melakukan perencanaan yang berkaitan dengan pengelolaan dana keuangannya secara baik agar saat terjadi klaim dari peserta, perusahaan dapat melakukan kewajibannya sebagai penyelenggara asuransi secara optimal. Oleh karena itu, agar pemberian manfaat bagi peserta dapat dilakukan secara maksimal maka PT TASPEN (Persero) perlu menghasilkankinerja-kinerja yang berorientasi pada pemerolehan laba bagi perusahaan.Berdasarkan uraian diatas, tujuan pnelitian ini adalah untuk mengetahui pengaruhpengelolaan investasi terhadap laporan keuangan pada Yayasan Tunjangan Hari Tua Bank Sumsel Babel.

\section{B. KAJIAN PUSTAKA}

1) Pengertian Pengelolaan

Pengelolaan merupakan kegiatan

yang sangat dibutuhkan suatu perusahan dalam meningkatan pendapatan. Pengelolaan yang baik membuat suatu perusahaan dapat di kategorikan termasuk perusahaan yang baik. Pengelolaan dalam istilah Bahasa Indonesia dapat disamakan dengan manajemen.Manajemen bertalian dengan bimbingan orangorang dan fungsi untuk mencapai tujuan-tujuan yang telah ditetapkan sebelumnya (Pfiffner, 2012 ).

\section{2) Pengertian Investasi Menurut Martalena}

(2011) investasi adalah bentuk penundaan konsumsi di masa sekarang untuk memperoleh konsumsi di masa yang akan datang, dimana didalamnya terkandung unsur risiko ketidakpastian sehingga dibutuhkan kompensasi atas penundaan tersebut, sedangkan menurut Jogiyanto (2013) investasi adalah penundaan konsumsi sekarang unu dimasukkan ke aktiva produktif selama periode waktu tertentu.

Investasi ke dalam aktiva keuangan dapat berupa investasi langsung dan investasi tidak langsung. Investasi langsung dilakukan dengan membeli langsung aktiva keuangan dari suatu perusahaan baik melalui perantara atau dengan cara yang lain. Sebaliknya investasi tidak langsung dilakukan dengan membeli saham dari perusahaan investasi yang membeli portofolio aktiva-aktiva keuangan dari perusahaan-perusahaan lain.

Gambar 1 Investasi Langsung dan Investasi Tidak Langsung Investasi tidak

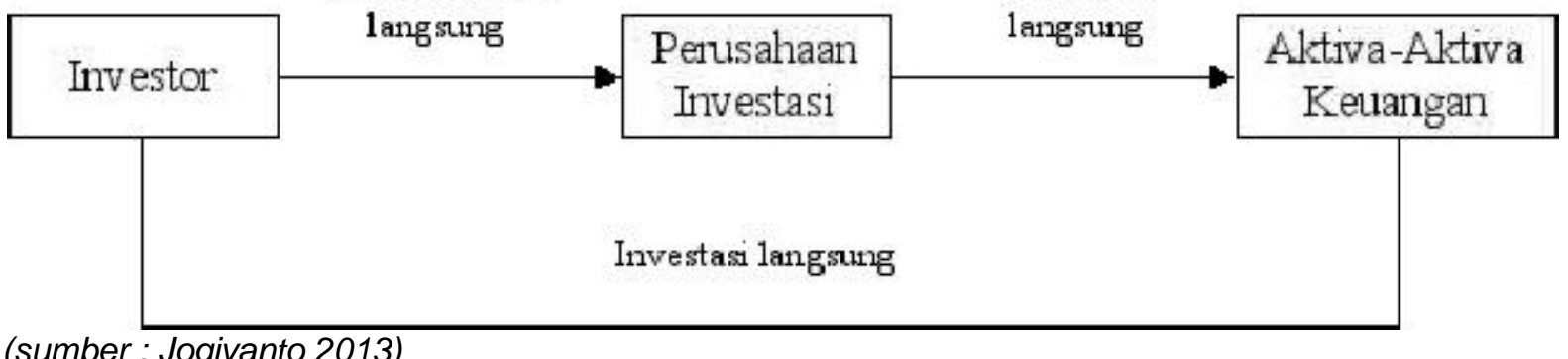

(sumber : Jogiyanto 2013) 
Menurut Jogiyanto (2013) jenisjenis risiko yang umumnya dihadapi perusahaan dalam investasi yaitu : 1) Business Risk (Risiko Bisnis); 2) Financial Risk (Risiko Finansial); 3) Inflation Risk / Purchasing Power Risk (Risiko Inflasi / Penurunan Daya beli); 4) Interest Rate Risk (Risiko Suku Bunga); 5) SocialRisk(RisikoSosial); 6) Foreign Exchange Risk (Risiko Nilai Tukar); 7) Political Risk (Risiko Situasi Politik).

Menurut Tandellin (2010) tujuan investasi adalah sebagai berikut :

1. Untuk mendapatkan kehidupan yang lebih layak di masa depan. Seseorang memiliki persepsi bagaimana ia dapat meningkatkan taraf hidupnya di masa yang akan datang atau setidaknya berusaha bagaimana seseorang tersebut mempertahankan pendapatan yang sekarang agar tidak berkurang dari nilai sekarang.

2. Mengurangi tekanan inflasi, dengan melakukan investasi dalam pemilik perusahaan atau obyek lainnya, seseorang dapat menghindarkan dirinya dari sebuah risiko penurunan nilai kekayaan atau hak miliknya akibat adanya pengaruh inflasi.

3. Adanya dorongan untuk menghemat pajak, beberapa negara di dunia banyak yang melakukan kebijakan yang bersifat mendorong pertumbuhan investasi di kalangan masyarakat melalui pemberian fasilitas perpajakan pada masyarakat yang melakukan investasi di bidang- bidang tertentu.

Menurut Sutrisno (2009) jenisjenis investasi dapat digolongkan berdasarkan aset, pengaruh,ekonomi, menurut sumbernya dan cara penanamannya, sebagai berikut:
1) Jenis Investasi Berdasarkan Asetnya

Jenis investasi berdasarkan asetnya merupakan penggolongan investasi dari aspek modal atau kekayaan. Investasi berdasarkan asetnya terbagi atas dua jenis, yaitu real asset dan financial asset. Real Asset adalah investasi yang berwujud seperti gedung-gedung, kendaraan dan lain sebagainya, sedangkan Financial

Asset merupakan dokumen (surat-surat) klaim tidak langsung dari pemegangnya terhadap aktivitas riil pihak yang menerbitkan sekuritas tersebut.

2) Jenis Investasi Bedasarkan Pengaruhnya

Jenis investasi menurut pengaruhnya merupakan investasi yang didasarkan pada faktor-faktor yang memengaruhi atau tidak berpengaruh dari kegiatan investasi. Jenis investasi berdasarkan pengaruhnya dapat dibagi lagi menjadi dua macam, yaitu investasi autonomus (berdiri sendiri) dan Investasi Induces (memengaruhi atau menyebabkan).

Investasi Autonomus adalah investasi yang tidak dipengaruhi oleh tingkat pendapatan, bersifat spekulatif. Contoh investasi ini : pembelian surat-surat berharga. Investasi Inducedialah investasi yang dipengaruhi kenaikan permintaan akan barang dan jasa serta tingkat pendapatan. Contoh investasi ini : penghasilan transitori, yaitu penghasilan yang diperoleh selain dari bekerja, seperti bungan dan sebagainya.

3) Jenis Investasi Berdasarkan Sumber Pembiayaannya

Jenis investasi berdasarkan sumber pembiayaannya merupakan investasi yang didasarkan pada asal-usul 
investasi yang diperoleh.Jenis investasi ini dapat dibagi lagi menjadi dua macam, yaitu investasi yang besumber dari modal asing dan investasi yang bersumber dari modal dalam negeri.

4) Jenis Investasi berdasarkan bentuknya.

Jenis investasi ini merupakan investasi yang didasarkanpada cara menanamkan investasinya. Jenis investasi ini dapat dibagi menjadi dua macam, yaitu investasi portofolio dan investasi langsung.Investasi Portopolio dilakukan melalui pasar modal dengan instrumen surat berharga, contohnya seperti saham dan obligasi. Investasi langsung merupakan bentuk investasi yang dilakukan dengan membangun, membeli total, atau mengakuisi suatu perusahaan.

\section{3) Deposito Berjangka}

Deposito adalah simpanan pihak ketiga pada bank yang penarikannya hanya dapat dilakukan dalam jangka waktu tertentu sesuai dengan kesepakatan antara bank dan deposan.Bukti kepemilikan deposito berjangka ini adalah bilyet deposito atas nama sehingga tidak dapat diperjualbelikan. Pada umumnya, jangka waktu deposito adalah 1 bulan, 3 bulan, 6 bulan, dan 12 bulan, namun ada juga beberapa bank yang memberikan jangka waktu kurang dari 1 bulan, misalnya 1 minggu. (Mintardjo, 2010)

\section{4) Saham}

Menurut Darmadji (2011), sahamdidefinisikan sebagai tanda pernyataan atau pemilikan seseorang atau badan dalam suatu perusahaan atau perseroan terbatas. Saham berwujud selembar kertas yang menerangkanbahwa pemilik kertas tersebut adalah pemilik perusahaan yang menerbitkan surat berharga tersebut Investasi dengan membeli saham suatu perusahaan, berarti investor telah menginvestasikan dana dengan harapan akan mendapatkan keuntungan dari hasil penjualan kembali saham tersebut.

Wujud saham adalah selembar kertas yang menerangkan bahwa pemilik kertas tersebut adalah pemilik perusahaan yang menerbitkan surat berharga tersebut dan porsi kepemilikan ditentukan oleh seberapa besar penyertaan yang ditanamkan dalam perusahaan tersebut (Darmadji, 2011). Sifat dasar investasi saham adalah memberikan peran bagi investor dalam memperoleh laba perusahaan.Setiap pemegang saham merupakan sebagian pemilik perusahaan, sehingga mereka berhak atas sebagian dari laba perusahaan. Namun hak tersebut terbatas karena pemegang saham berhak atas bagian penghasilan perusahaan hanya setelah seluruh kewajiban perusahaan dipenuhi.

\section{5) Obligasi}

Obligasi merupakan surat berharga yang dijual kepada publik, dimana disana dicantumkan berbagai ketentuan yang menjelaskan berbagai hal seperti nilai nominal, tingkat suku bunga, jangka waktu, nama penerbit dan beberapa ketentuan lainnya yang terjelaskan dalam undang-undang yang disahkan oleh lembaga yang terkait. (Fahmi, 2013), sedangkan menurut Rudianto (2012) adalah Surat utang yang diterbitkan oleh suatu perusahaan berupa janji untuk membayar sejumlah utang (seperti yang tercantum dalam nominal obligasi) di kemudian hari beserta pembayaran bunganya secara berkala. 


\section{6) Laporan Keuangan}

Menurut Standart Akuntansi Keuangan (PSAK No.1 tahun 2018), laporan keuangan merupakan bagian dari proses pelaporan keuangan. Laporan keuangan yang lengkap biasanya meliputi neraca, laporan labarugi, laporan perubahan posisi keuangan (yang dapat disajikan dalam berbagai cara misalnya, sebagai laporan arus kas, atau laporan arus dana), catatan dan laporan lain serta materi penjelasan yang merupakan bagianintegral dari laporan keuangan. Disamping itu juga termasuk skedul daninformasi tambahan yang berkaitan dengan laporan tersebut, misalnya, informasi keuangan segmen industri dan geografis serta pengungkapan pengaruh perubahan harga.
Syarat-syarat laporan keuangan (Wiratna, 2017) merupakan ciri khas membuat informasi dalam laporan keuangan yang berguna agi para pemakai dalam pengambilan keputusan bernilai ekonomis adalah : 1) Dapat dipahami; 2) Relevan; 3) Keandalan; 4) Dapat dibandingkan; 5) Mempunyai daya uji; 6) Netral; 7) Tepat waktu; 8) Lengkap

\section{7) Perbankan}

Menurut Kasmir (2014), perbankan adalah badan usaha yang menghimpun dana dari masyarakat dalam bentuk simpanan dan menyalurkannya kembali kepada masyarakat dalam bentuk kredit dan atau bentuk-bentuk lainnya dalam rangka meningkatkan taraf hidup rakyat banyak.

\section{Gambar 2.Kerangka Berfikir}

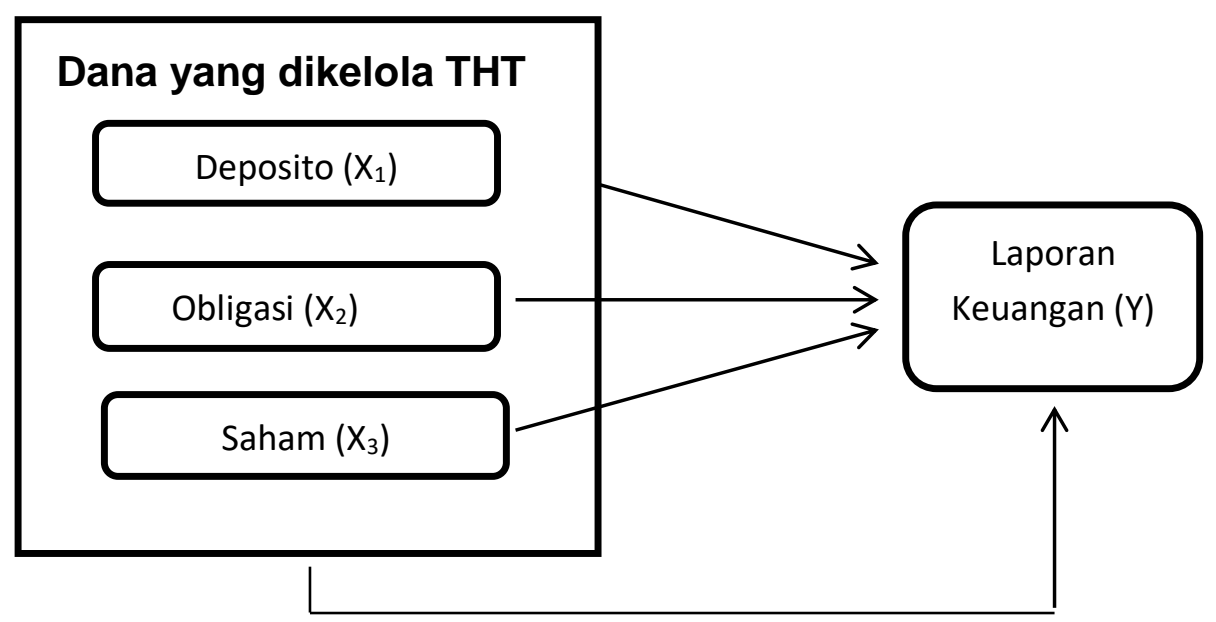

\section{Hipotesis}

$\mathrm{H}_{1}=$ Terdapat pengaruh signifikan pendapatan bunga deposito terhadap Laporan Keuangan pada Yayasan Tunjangan Hari Tua Bank Sumsel Babel.

$\mathrm{H}_{2}=$ Terdapat pengaruh signifikan pendapatan obligasi terhadap laporan keuangan pada Yayasan Tunjangan Hari Tua Bank Sumsel Babel.
$\mathrm{H}_{3}=$ Terdapat pengaruh signifikan pendapatan hasil saham terhadap laporan keuagan pada Yayasan Tunjangan Hari Tua Bank Sumsel Babel.

$\mathrm{H}_{4}=$ Terdapat pengaruh signifikan pendapatan hasil dari deposito, obligasi, dan saham terhadap laporan keuagan pada Yayasan Tunjangan Hari TuaBank Sumsel Babel 


\section{METODOLOGI PENELITIAN}

Penelitian ini dilakukan di Yayasan Tunjangan Hari Tua Bank Sumsel Babel yang beralamat di $\mathrm{Jl}$. G.H. Bastari Komp. Opi Business Centre Blok D2 No.16 LT.III Jakabaring Seberang Ulu 1 Palembang. Agar peneletian ini lebih terfokus maka penelitian ini memiliki ruang lingkup yang spesifik, yaitu penelitian ini hanya di lakukan pada Yayasan Tunjangan Hari Tua Bank Sumsel Babel. Data yang diambil dari laporankeuangan adalah neraca, arus kas, aktiva bersih, dan pendapatan hasil investasi selama periode penelitian yaitu pada tahun 2014-2017.

Teknik pengumpulan data yang digunakan dalam penelitian ini yaitu metode dokumentasi dengan mengambil data laporan keuangan bulanan Yayasan Tunjangan Hari Tua Bank Sumsel Babel dari tahun 20142017. Penelitian ini juga menggunakan analisis regresi linier berganda untuk analisis pengaruh dari variabel bebas terhadap variabel terikat. Persamaan regresi linear sederhana pada penelitian ini adalah sebagai berikut:

$$
Y=a+b_{1} X_{1}+b_{2} X_{2}+b_{3} X_{3}+e
$$

\section{Keterangan :}

$\mathrm{Y}=$ Laporan Keuangan

$\mathrm{a}=$ Konstanta

$\mathrm{b}_{1}-\mathrm{b}_{3}=$ Koefisien Regresi
$\mathrm{X}_{1}=$ Hasil dari pendapatan bunga Deposito,

$\mathrm{X}_{2}=$ Hasil dari pendapatan bunga Obligasi

$\mathrm{X}_{3}=$ Hasil dari dividen Saham

e $=$ error term

\section{HASIL PENELITIAN DAN PEMBAHASAN}

Penelitian ini dilakukan untuk mengetahui pengaruh dari pengelolaan investasi terhadap laporan keuangan pada Yayasan Tunjangan Hari Tua Bank Sumsel Babel periode 20142017. Penelitian ini menggunakan data sekunder yang diperoleh langsung dari kantor Yayasan Tunjangan Hari Tua Bank Sumsel Babel. Data yang digunakan dalam penelitian ini adalah Laporan Keuangan, Deposito, Obligasi, dan Saham. Variabel dependen dalam penlitian ini adalah Laporan Keuangan, sedangkan variable independen yang digunakan yaitu Deposito, Obligasi, dan Saham.

Uji prasyarat analisis dalam penelitian ini menggunakan uji asumsi klasik sebagai syarat sebelum dilakukan analisis regresi. Uji asumsi klasik yang dilakukan, yaitu uji normalitas dengan menggunakan uji Shapiro Wilk, uji autokorelasi dengan menggunakan Durbin Watson, uji multikolinearitas dengan Variance Inflation Factor (VIF), dan uji heteroskedastisitas yang dilakukan dengan uji Scaterplot.

\section{Uji Asumsi Klasik}

Tabel 1 Hasil Pengujian Normalitas uji Shapiro Wilk Tests of Normality

\begin{tabular}{|l|r|r|r|r|r|r|}
\hline & \multicolumn{3}{|c|}{ Kolmogorov-Smirnov ${ }^{\mathrm{a}}$} & \multicolumn{3}{|c|}{ Shapiro-Wilk } \\
\cline { 2 - 7 } & Statistic & \multicolumn{1}{c|}{ df } & \multicolumn{1}{c|}{ Sig. } & Statistic & \multicolumn{1}{c|}{ df } & \multicolumn{1}{c|}{ Sig. } \\
\hline Deposito &, 224 & 48 &, 097 &, 950 & 48 &, 643 \\
Obligasi &, 089 & 48 &, $200^{*}$ &, 967 & 48 &, 876 \\
Saham &, 089 & 48 &, $200^{*}$ &, 967 & 48 &, 876 \\
\hline
\end{tabular}

${ }^{\star}$. This is a lower bound of the true significance.

a. Lilliefors Significance Correction

Sumber : Hasil olahan spss v22, 2019 
Berdasarkan tabel diatas, uji normalitas menunjukan nilai Asymp. Sig (2-tailed) diatas 0,05. Hal tersebut menunjukan bahwa data berdistribusi normal karena nilai Asymp. Sig (2tailed) > 0,05. Dengan demikian $\mathrm{H}_{\mathrm{o}}$ diterima dan $\mathrm{H}_{\mathrm{a}}$ ditolak.

Tabel 2 Hasil Pengujian Multikolineritas

Coefficients $^{a}$

\begin{tabular}{|c|c|c|c|c|c|c|c|}
\hline \multirow[b]{2}{*}{ Model } & \multicolumn{2}{|c|}{$\begin{array}{l}\text { Unstandardized } \\
\text { Coefficients }\end{array}$} & \multirow{2}{*}{$\begin{array}{c}\text { Standardized } \\
\text { Coefficients } \\
\text { Beta } \\
\end{array}$} & \multirow[b]{2}{*}{$t$} & \multirow[b]{2}{*}{ Sig. } & \multicolumn{2}{|c|}{$\begin{array}{l}\text { Collinearity } \\
\text { Statistics }\end{array}$} \\
\hline & $B$ & Std. Error & & & & Tolerance & VIF \\
\hline (Constant) & 6209472 & 4300171 & & 14,440 & ,000 & & \\
\hline Deposito & 51,880 & 13,357 & 359 & 3,884 & ,000 & ,704 & 1,420 \\
\hline Obligasi & 47,596 & 18,717 & ,227 & 2,543 & ,015 & 805 & 1,242 \\
\hline Saham & 6,575 & ,981 & ,656 & 6,700 & ,000 & 655 & 1,526 \\
\hline
\end{tabular}

a. Dependent Variable: Lap Keuangan

Sumber : Hasil olahan spss v22, 2019

Berdasarkan tabel diatas, semua variabel menunjukan nilai tolerance > 0,10 , dan VIF $<10$, sehingga dapat disimpulkan bahwa pada penelitian ini bebas dari masalah multikolinearitas. Oleh karena itu, model regresi ini layak untuk digunakan dalam penelitian.

\section{Gambar 3. Hasil Pengujian Heteroskedastisitas dengan uji Scatterplot (Lampiran 6)}

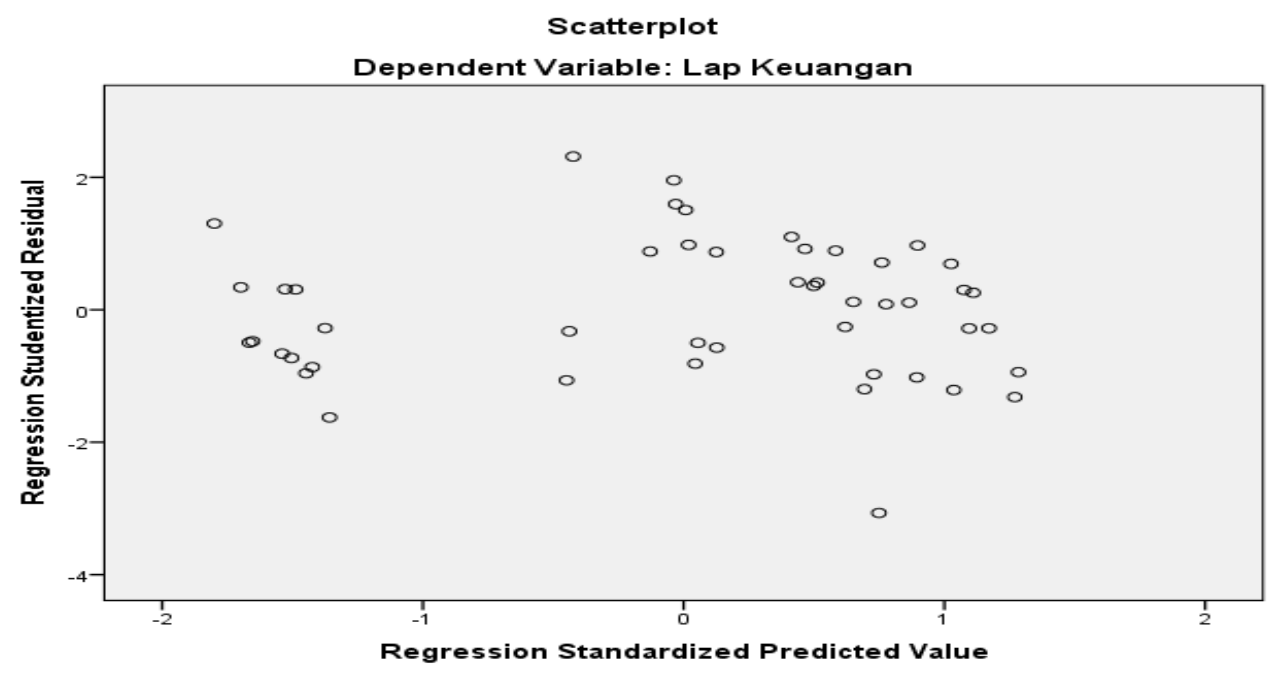

Sumber : Hasil olahan spss v22, 2019

Berdasarkan grafik scatterplot diatas, terlihat bahwa titik-titik menyebar dan tidak membentuk pola tertentu yang jelas, sehingga dapat disimpulkan bahwa dalam pengujian diatas tidak terjadi masalah heteroskedastisitas. 
Tabel 3 Hasil Uji Autokorelasi dengan Durbin Watson

Model Summary

\begin{tabular}{|l|c|r|r|r|r|}
\hline Model & $\mathrm{R}$ & $\begin{array}{c}\mathrm{R} \\
\text { Square }\end{array}$ & $\begin{array}{c}\text { Adjusted R } \\
\text { Square }\end{array}$ & $\begin{array}{c}\text { Std. Error of } \\
\text { the Estimate }\end{array}$ & $\begin{array}{c}\text { Durbin- } \\
\text { Watson }\end{array}$ \\
\hline 1 &, $857^{\mathrm{a}}$ &, 735 &, 717 & 430080376 & 1,777 \\
\hline
\end{tabular}

a. Predictors: (Constant), Deposito,Obligasi,Saham

b. Dependent Variable: Lap Keuangan

Sumber : Hasil olahan spss v22, 2019

Berdasarkan hasil pegujian yang dilakukan maka diperoleh angka DW sebesar 1,777. Dalam tabel DW untuk $\mathrm{k}=3$ dan $\mathrm{N}=48$. Nilai batas bawah (dl) sebesar 1,4064 dan nilai batas atas (du) sebesar 1,6708. Nilai DW berada pada kondisi di antara nilai du dan 4-du. Hal ini menunjukan bahwa nilai DW 1,777 berada diantara batas atas (du) 1,6708 dan nilai 4(du) 2,3292 maka tidak terjadi autokorelasi.

\section{Analisis Regresi Linear Berganda}

Tabel 4 Hasil Uji Regresi Linear Berganda

Coefficients $^{\mathrm{a}}$

\begin{tabular}{|c|c|c|c|c|c|}
\hline \multirow[b]{2}{*}{ Model } & \multicolumn{2}{|c|}{$\begin{array}{l}\text { Unstandardized } \\
\text { Coefficients }\end{array}$} & \multirow{2}{*}{$\begin{array}{c}\text { Standardized } \\
\text { Coefficients } \\
\text { Beta }\end{array}$} & \multirow[b]{2}{*}{$\mathrm{t}$} & \multirow[b]{2}{*}{ Sig. } \\
\hline & $B$ & Std. Error & & & \\
\hline (Constant) & 6209472 & 4300171 & & 14,440 &, 000 \\
\hline Deposito & 51,880 & 13,357 & ,359 & 3,884 & ,000 \\
\hline Obligasi & 47,596 & 18,717 & ,227 & 2,543 & 015 \\
\hline Saham & 6,575 &, 981 & 656 & 6,700 &, 000 \\
\hline
\end{tabular}

a. Dependent Variable: Lap Keuangan

Sumber : Hasil olahan spss v22, 2019

Berdasarkan hasil tabel 4 menunjukan diperoleh nilai koefisien konstanta sebesar 6209472, koefisien Deposito 51,880, koefisien Obligasi 47,596, koefisien Saham 6,575. Maka persamaan model regresinya adalah sebagai berikut :

$\mathrm{Y}=6209472+51,880$ Deposito + 47,596 Obligasi + 6,575 Saham

\section{Uji Statistik t}

Tabel 5 Hasil Uji $t$

Coefficients $^{\mathrm{a}}$

\begin{tabular}{|c|c|c|c|c|c|}
\hline \multirow[b]{2}{*}{ Model } & \multicolumn{2}{|c|}{$\begin{array}{l}\text { Unstandardized } \\
\text { Coefficients }\end{array}$} & \multirow{2}{*}{$\begin{array}{c}\text { Standardized } \\
\text { Coefficients } \\
\text { Beta }\end{array}$} & \multirow[b]{2}{*}{$\mathrm{t}$} & \multirow[b]{2}{*}{ Sig. } \\
\hline & $B$ & Std. Error & & & \\
\hline (Constant) & 6209472 & 4300171 & & 14,440 & ,000 \\
\hline Deposito & 51,880 & 13,357 & 359 & 3,884 & , 000 \\
\hline Obligasi & 47,596 & 18,717 & 227 & 2,543 & ,015 \\
\hline Saham & 6,575 & ,981 & ,656 & 6,700 &, 000 \\
\hline
\end{tabular}

a. Dependent Variable: Lap Keuangan

Sumber: Hasil olahan spss v22, 2019 
Berikut penjelasan masingmasing hipotesis dari hasil pengujian regresi linear berganda diatas yaitu sebagai berikut :

1. Pengujian hipotesis pertama $\left(\mathrm{H}_{1}\right)$

Pengujian hipotesis pertama dalam penelitian ini adalah diketahui nilai Sig. untuk pengaruh deposito $\left(\mathrm{X}_{1}\right)$ terhadap laporan keuangan (Y) adalah sebesar $0,00<0,05$ dan nilai t hitung 3,884> t tabel 2,015, sehingga dapat disimpulkan bahwa Hipotesis Pertama diterima yang berarti terdapat pengaruh $\mathrm{X}_{1}$ terhadap $\mathrm{Y}$.

2. Pengujian hipotesis kedua $\left(\mathrm{H}_{2}\right)$ Pengujian hipotesis kedua dalam penelitian ini adalah diketahui nilai
Sig. untuk pengaruh obligasi $\left(\mathrm{X}_{2}\right)$ terhadap laporan keuangan (Y) adalah sebesar 0,015 $<0,05$ dan nilai t hitung 2,543> t tabel 2,015, sehingga dapat disimpulkan bahwa obligasi diterima yang berarti terdapat pengaruh $\mathrm{X}_{2}$ terhadap $\mathrm{Y}$.

3. Pengujian hipotesis ketiga $\left(\mathrm{H}_{3}\right)$ Pengujian hipotesis ketiga dalam penelitian ini adalah diketahui nilai Sig. untuk pengaruh saham $\left(X_{3}\right)$ terhadap laporan keuangan (Y) adalah sebesar 0,357>0,05 dan nilai t hitung 6,700> t tabel 2,015, sehingga dapat disimpulkan bahwa hipotesis ketiga diterima yang berarti terdapat pengaruh positif $\mathrm{X}_{3}$ terhadap $\mathrm{Y}$.

\section{Uji Statistik F}

Tabel 6 Hasil Uji F

ANOVA $^{a}$

\begin{tabular}{|c|c|c|c|c|c|}
\hline & Sum of Squares & $\mathrm{df}$ & Mean Square & $\bar{F}$ & Sig. \\
\hline \multirow{3}{*}{$\begin{array}{ll}1 & \text { Regression } \\
& \text { Residual } \\
\text { Total }\end{array}$} & 2253185660233144900000,000 & 3 & 751061886744381600000,000 & 40,596 &, $000^{b}$ \\
\hline & 814040933264019800000,000 & 44 & 18500930301454995000,000 & & \\
\hline & 3067226593497165000000,000 & 47 & & & \\
\hline
\end{tabular}

a. Dependent Variable: Lap Keuangan

b. Predictors: (Constant), Deposito, Obligasi, Saham

Sumber : Hasil olahan spss v22, 2019

Berdasarkan tabel diatas didapatkan nilai $F$ hitung 40,596 dan nilai $F$ tabel $=$ $\mathrm{F}(\mathrm{k}: \mathrm{n}-\mathrm{k})=\mathrm{F}(3: 45)=2,81$. Nilai $\mathrm{F}$ hitung sebesar 40,596 dengan Sig. $0,000<0,05$ dan nilai $F$ hitung 40,596 $>\mathrm{F}$ tabel 2,81 , maka dalam pengujian hipotesis keempat $\left(\mathrm{H}_{4}\right)$ dapat disimpulkan bahwa Hipotesis keempat $\left(\mathrm{H}_{4}\right)$ diterima yang berarti terdapat pengaruh yang signifikan Deposito, Obligasi dan Saham terhadap Laporan Keuangan.

\section{Koefisien Determinasi}

Tabel 7 Hasil Uji Koefisien Determinasi

Model Summary ${ }^{b}$

\begin{tabular}{|l|c|r|r|r|r|}
\hline $\begin{array}{l}\text { Mode } \\
\mathrm{I}\end{array}$ & $\mathrm{R}$ & $\begin{array}{c}\mathrm{R} \\
\text { Square }\end{array}$ & $\begin{array}{c}\text { Adjusted R } \\
\text { Square }\end{array}$ & $\begin{array}{c}\text { Std. Error of } \\
\text { the Estimate }\end{array}$ & $\begin{array}{c}\text { Durbin- } \\
\text { Watson }\end{array}$ \\
\hline 1 &, $857^{\mathrm{a}}$ &, 735 &, 717 & 430080376 & 1,777 \\
\hline
\end{tabular}

a. Predictors: (Constant), Deposito,Obligasi,Saham

b. Dependent Variable: Lap Keuangan

Sumber: Hasil olahan spss v22, 2019 
Berdasarkan tabel 7 diatas dapat diketahui besarnya adjusted $R$ square yaitu sebesar 0,717 atau $71,7 \%$. Angka tersebut mengandung arti bahwa variabel Deposito $\left(X_{1}\right)$, variabel Obligasi $\left(\mathrm{X}_{2}\right)$, dan variabel Saham $\left(\mathrm{X}_{3}\right)$ secara simultan (bersama-sama) berpengaruh terhadap variabel Laporan Keuangan (Y) sebesar 71,7 $\%$. Sedangkan sisanya $28,3 \%$ di pengaruhi oleh variabel lain diluar persamaan regresi ini atau variabel yang tidak di teliti.

\section{Pengaruh pendapatan hasil dari Deposito terhadap laporan keuangan pada Yayasan THT Bank Sumsel Babel}

Hasil uji hipotesis dengan uji $t$ menunjukkan bahwa deposito berpengaruh positif dan optimal terhadap laporan keuangan, hal ini dapat dilihat dari perhitungan uji $\mathrm{t}$ dimana t hitung 3,884> t tabel 2,015. Hal ini mungkin terjadi karena pendapatan deposito mendapatkan hasil yang tinggi dan signifikan. Semakin tinggi pendapatan deposito maka semakin berpengaruh pada laporan keuangan. Hasil uji hipotesis ini mendukung hasil penelitian Rulyanto (2008) dimana hasil investasi Deposito berpengaruh secara optimal terhadap kinerja laporan keuangannya.

Deposito adalah bentuk investasi yang memiliki masa jangka waktu yaitu 1 bulan, 3 bulan, 6 bulan, dan 12 bulan dengan bunga deposito yang akan diterima setiap tanggal penempatan dana tersebut. Penarikan dapat dilakukan secara tunai maupun non tunai (pemindahbukuan) dan setiap bunga deposito dikenakan pajak dari jumlah bunga yang diterimanya. Maka, perlakukan atas investasi Deposito memberikan peningkatan terhadap kinerja laporan keuangan.
Suatu Yayasan atau Perusahaan yang melakukan investasi dalam bentuk deposito akan memberikan peningkatan terhadap hasil usaha yang berdampak terhadap laporan keuangan apabila semakin besar rate/ suku bunga deposito tinggi maka akan semakin besar hasil yang akan diperoleh.

\section{Pengaruh pendapatan hasil dari Obligasi terhadap laporan keuangan pada Yayasan THT Bank Sumsel Babel}

Pengujian hipotesis ini dengan uji $\mathrm{t}$ menunjukkan bahwa obligasi juga berpengaruh positif terhadap laporan keuangan, hal ini dilihat dari hasil hipotesis uji t dimana nilai Sig 0,015 < 0,05 dan nilai t hitung 2,543 > t tabel 2,015. Sehingga hasil pengujian hipotesis ini mendukung hasil penelitian Rulyanto (2008) bahwa investasi Obligasi menunjukan pengaruh yang positif terhadap laporan keuangan pada PT.TASPEN (Persero).

Obligasi merupakan surat berharga yang dijual kepada publik, dimana dicantumkan berbagai ketentuan yang menjelaskan berbagai hal seperti nilai nominal, tingkat suku bunga, jangka waktu, nama penerbit dan beberapa ketentuan lainnya yang terjelaskan dalam undang-undang yang disahkan oleh lembaga yang terkait.Nilai nominal atau nilai utang pokok harus dibayar bunganya oleh penerbit dan harus dilunasi pada saat akhir masa jatuh tempo. Obligasi akan memberikan manfaat berupa kupon pembayaran bunga, dimana bunga tersebut akan memberikan peningkatan atas hasil dari investasi tersebut terhadap laporan keuangan. 
Pengaruh pendapatan hasil dari Saham terhadap laporan keuangan pada Yayasan THT Bank Sumsel Babel

Pengujian hipotesis ini menunjukkan bahwa saham berpengaruh positif terhadap laporan keuangan Yayasan THT BSB yang dapat dilihat dari hasil uji t dengan nilai $\mathrm{t}$ hitung 6,700> t tabel 2,015. Hasil pengujian tersebut sejalan dengan penelitian Sayuti dkk (2015) bahwa investasi saham yang memiliki pengaruh terhadap laporan keuangan pada DAPENSRI PT.Pupuk Sriwidjaja .

Saham merupakan sertifikat yang menunjukkan bukti kepemilikan suatu perusahaan dan pemegang saham memiliki hak klaim atas penghasilan dan aktiva perusahaan serta berhak hadir dalam Rapat Umum Pemegang Saham (RUPS). Menerbitkan saham merupakan salah satu pilihan perusahaan dalam memutuskan pendanaan perusahaannya.

Investasi dalam bentuk saham akan memberikan peningkatan hasil dari investasi berupa dividen yang akan dibayarkan disetiap tahunnya dan investasi dengan membeli saham suatu perusahaan, berarti investor telah menginvestasikan dana dengan harapan akan mendapatkan keuntungan dari hasil penjualan kembali saham tersebut.

Pengaruh pendapatan hasil dari Deposito, Obligasi, dan Saham terhadap laporan keuangan pada Yayasan THT Bank Sumsel Babel

Berdasarkan analisis data yang telah dilakukan, maka dapat disimpulkan variabel deposito, obligasi, dan saham bersama - sama berpengaruh positif terhadap laporan keuangan yang dibuktikan dengan nilai $\mathrm{F}$ hitung 40,596 > F tabel 2,81. Hal tersebut membuktikan bahwa pendapatan hasil investasi pada deposito, obigasi, dan saham secara bersama-sama mempengaruhi laporan keuangan pada Yayasan Tunjangan Hari Tua Bank Sumsel Babel. Hasil ini sejalan dengan penelitian Patriani (2012) dimana perlakuan atas investasi Deposito, Obligasi, dan Saham secara bersama- sama memberikan pengaruh positif terhadap laporan keuangan Asuransi Jiwa Syariah dan Konvensional.

Maka dapat disimpulkan melakukan penempatan dana dalam bentuk investasi berupa Deposito, Obligasi dan Saham hasil atas investasi tersebut dapat mempengaruhi kinerja Laporan Keuangan suatu perusahaan seperti pada Yayasan Tunjangan Hari Tua Bank Sumsel Babel.

\section{KESIMPULAN DAN SARAN}

Kesimpulan

Berdasarkan hasil uji analis secara statistik maka diperoleh pada koefisien determinasi (adjusted $R$ square) menunjukkan Deposito $\left(\mathrm{X}_{1}\right)$, Obligasi $\left(X_{2}\right)$, dan Saham $\left(X_{3}\right)$ memiliki hubungan dan berpengaruh yang positif terhadap Laporan Keuangan ( $\mathrm{Y}$ ) sebesar $71,7 \%$. Sedangkan sisanya $(100 \%-71,7 \%=28,3 \%)$ di pengaruhi oleh variabel lain diluar persamaan regresi ini atau variabel yang tidak di teliti. Untuk hasil uji secara serentak didapatkan hasil bahwa semua variabel bebas berpengaruh secara signifikan tethadap variabel terikat, demikian pula hasil uji secara parsial (uji-t) variabel deposito,obligasi, dan saham juga mempunyai pengaruh signifikan terhadap kinerja dan pencapaian pada Laporan Keuangan.

\section{Saran}

Penelitian ini memiliki keterbatasan pada tahun observasi yang terbatas hanya menggunakan rentang waktu 4 tahun dan 
penggunaan variabel pada penelitian ini hanya berfokus pada Deposito, Obligasi, dan Saham. Untuk itu bagi perusahaan yang ingin berinvestasi sebaiknya lakukan kegiatan investasi dalam berbagai macam bentuk investasi dengan memperhatikan tingkat resiko untuk mendapatkan hasil yang optimal. Sedangkan bagi peneliti selanjutnya yang akan meneliti topik yang sama disarankan untuk menambah variabel dalam model penelitian serta menggunakan rentang waktu yang lebih lama agar memberikan hasil yang optimal misalnya variabel Surat Berharga, Deposito On Call, Sukuk, dan lain-lain.

1) Pada koefisien determinasi (adjusted $R$ square) menunjukkan Deposito $\left(\mathrm{X}_{1}\right)$, Obligasi $\left(\mathrm{X}_{2}\right)$, dan Saham $\left(X_{3}\right)$ memiliki hubungan dan berpengaruh yang positif terhadap Laporan Keuangan (Y) sebesar $71,7 \%$. Sedangkan sisanya $(100 \%-71,7 \%=28,3 \%)$ di pengaruhi oleh variabel lain diluar persamaan regresi ini atau variabel yang tidak di teliti.

2) Secara parsial (uji-t) variabel deposito,obligasi, dan sahamjuga mempunyai pengaruh signifikan terhadap kinerja dan pencapaian pada Laporan Keuangan.

3) Penelitian ini memeiliki keterbatasan pada tahun observasi yang terbatas hanya menggunakan rentang waktu 4 tahun dan penggunaan variabel pada penelitian ini hanya berfokus pada Deposito, Obligasi, dan Saham

4) Bagi Perusahaan yang ingin berinvestasi sebaiknya lakukan kegiatan investasi dalam berbagai macam bentuk investasi dengan memperhatikan tingkat resiko untuk mendapatkan hasil yang optimal.
5) Bagi peneliti selanjutnya yang akan meneliti topik yang sama disarankan untuk menambah variabel dalam model penelitian serta menggunakan rentang waktu yang lebih lama agar memberikan hasil yang optimal misalnya variabel Surat Berharga, Deposito On Call, Sukuk, dan lain-lain.

\section{DAFTAR PUSTAKA}

Aniqoh, Romiati Erie. 2008. Fungsi Bagian Investasi dalam Pengelolaan Dana Asuransi Umum Bumida Bumi Putera Syariah. Jakarta

Bank Sumsel Babel. 2014-2017. Laporan Portofolio Investasi Yayasan THT Bank Sumsel Babel.

Darmadji. 2011. Pasar Modal Di Indonesia. Edisi Ketiga. Jakarta : Salemba Empat

Fahmi, Irham. 2013. Analisis Laporan Keuangan. Cetakan Ketiga. Bandung

Husnan, Suad. 2015. Dasar-dasar Portofolio dan Analilsis Sekuritas.Yogyakarta

Ikatan Akuntansi Indonesia. 2018. Standar Akuntansi Keuangan. PSAK 13. Jakarta

Jogiyanto, 2013. Teori Portofolio dan Analisis Investasi.Yogyakarta : BPFE

Kasmir, 2014. Dasar-Dasar Perbankan. Edisi Revisi 2008. Jakarta : PT. Raja Grafindo Persada 
Martalena, 2011. Pengantar Pasar Modal. Edisi Pertama. Yogyakarta: Andi

Mintardjo, R. 2010. Praktek Akuntansi Bank. Jakarta: Salemba Empat.

Patriani, Gena Natasha.2012. Analisis Pengelolaan Dana Investasi Asuransi Jiwa Syariah Dan Konvensional serta Perlakuanya terhadap Hasil Investasi yang Diperoleh (Studi Kasus PT. Asuransi Jiwa $X Y Z$ ). Skripsi Universitas Indonesia. Depok

Pfiffner, 2012. Pengantar IImu Administrasi dan Managemen. Bandung : CV. Pustaka Setia

Purwanto. 2009. Evaluasi Hasil Belajar. Yogyakarta: Pustaka Belajar

Rudianto. 2012. Akuntansi Pengantar. Jakarta : Erlangga

Rulyanto, Sony. 2008. Analisis Pengelolaan Dana Tabungan Hari Tua pada PT. Taspen (Persero). Skripsi.Intitut Pertanian Bogor.
Sayuti, A Jalaludin. Syafitri, Ria. Silowati, Tri. 2015. Pengelolaan Investasi Dana Pensiun pada DAPENSRI PT. Pupuk Sriwidjaja Palembang. Jurnal Manajemen \& Bisnis Sriwijaya.Vol. 13 No. 1.

Sutrisno, Edi. 2009. Manajemen Sumber Daya Manusia Edisi pertama. Jakarta: Kencana Prenada Media Group

Tandellin, Eduardus. 2010. Portofolio dan Investasi. Edisi Pertama. Yogyakarta : Kasinius

Wiratna, Sujarweni. 2017. Metodologi Penelitian. Yogyakarta : PT. PUSTAKA BARU PRESS

www.ojk.go.id (diakses 20 Januari 219) www.sarjanaku.com. Dalam Jenis-jenis Resiko yng dihadapi Perushaan dalam Investasi. (diakses 28 Januari 2019)

www.scribd.com. Dalam Investasi dan Tipe Investasi Keuangan ke dalam Aktiva Keuangan. (diakses 28 Januari 2019) 